\section{International Scientific Journal Theoretical \& Applied Science}

p-ISSN: 2308-4944 (print) ｅ-ISSN: 2409-0085 (online)

Year: 2015 Issue: 05 Volume: 25

Published: $30.05 .2015 \quad$ http://T-Science.org

SECTION 8. Architecture and construction.
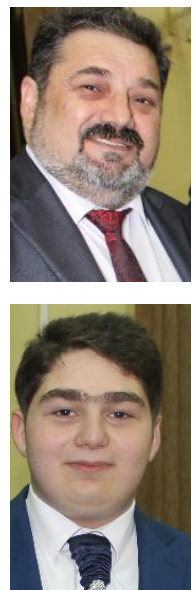

Gagik Sergeevch Ogandzhanian Candidate of technical sciences, CEO LLC "LAD Systems", Moscow, Russia LAD_Sistems@mail.ru

David Gagikovich Ogandzhanian Student «MATI - Russian State Technological University named after K.E.Tsiolkovsky», Moscow, Russia

\title{
INNOVATIVE SOLUTIONS OF PROBLEMS OF MULTILAYER OUTER BRICK WALLS WITH TILE EFFICIENT INSULATION IN MASS LOW BUDGET HOUSING CONSTRUCTION IN RUSSIA
}

Abstract: The article summarizes the main structural problems of multi-layer outer brick-clad walls with efficient insulation in low budget low or high-rise residential buildings in Russia, provides rationalization for developing scientific and technological basis for production of innovative composite wall foamthermoblock systems and using them when constructing multilayer outer walls. Rigid polyurethane foam, being used as high performance insulation material as well as material to form blocks, allows to make long-life building facades with the modest thicknesses and weigh with high thermotechnical, insulating and strength characteristics.

Key words: multi-layer wall, efficient insulant, rigid polyurethane, high adhesive property, composite wall foamthermoblock.

Language: English

Citation: Ogandzhanian GS, Ogandzhanian DG (2015) INNOVATIVE SOLUTIONS OF PROBLEMS OF MULTILAYER OUTER BRICK WALLS WITH TILE EFFICIENT INSULATION IN MASS LOW BUDGET HOUSING CONSTRUCTION IN RUSSIA. ISJ Theoretical \& Applied Science 05 (25): 144-149.

Soi: http://s-o-i.org/1.1/TAS*05(25)27 Doi: crossef http://dx.doi.org/10.15863/TAS.2015.05.25.27

\section{ИННОВАЦИОННЫЕ ВОЗМОЖНОСТИ РЕШЕНИЯ ПРОБЛЕМ МНОГОСЛОЙНЫХ НАРУЖНЫХ КИРПИЧНЫХ СТЕН С ПЛИТОЧНЫМ ЭФФЕКТИВНЫМ УТЕПЛИТЕЛЕМ В МАССОВОМ БЮДЖЕТНОМ ЖИЛИЩНОМ ДОМОСТРОЕНИИ РФ}

Аннотация: В статье обобщены основные конструктивные проблемы многослойных наружных стен c кирпичной облицовкой и эффективным утеплителем в бюджетном мало- и многоэтажном домостроении РФ, обоснована разработка научно-технической платформы по производству инновационных композитных стеновых пенатермоблоков и конструированию многослойных наружных стен из них. Использование жесткого пенаполиуретана в качестве эффективного утеплителя и блокообразующего материала позволит производить инновационные композитные стеновые блоки и устроить из них долговечные бюджетные фасады зданий наименьшей толщины и веса с высокими теплотехническими, пароизоляциионными и прочностными характеристиками.

Ключевые слова: многослойная стена, эффективный утеплитель; жесткий пенополиуретан, высокоадгезионные свойства, энергосберегающий фасад, инновационный композитный стеновой пенатермоблок.

Today about $25 \%$ of all facade structures of low / high-rise residential buildings in Russia have multilayer outer walls of hollow brick-work (face brick + insulant + reinforced concrete, lightweight concrete or ceramic block, etc.)

With introduction of new constructive solutions and optimization of energy consumption regulations for residential areas, the legal and regulatory basis, developed for precast large-panel house building, rapidly growing since mid-20 $0^{\text {th }}$ century, as well as for buildings with stone (brick) walls does not correlate to requirements of modern construction technologies.

Nevertheless, the volume of construction of residential low/high-rise buildings with similar brickclad wall structures has been growing since late $90 \mathrm{~s}$ in all Russian regions, on account of being in demand and relatively cheap. Each year about $80 \mathrm{mln}$ 
Impact Factor ISRA (India) $\quad=\mathbf{1 . 3 4 4}$

Impact Factor ISI (Dubai, UAE) $=\mathbf{0 . 8 2 9}$

based on International Citation Report (ICR)

Impact Factor GIF (Australia) $\quad \mathbf{0} \mathbf{0 . 3 5 6}$
Impact Factor JIF

Impact Factor SIS (USA)

Impact Factor РИНЦ (Russia) $=0.179$

Impact Factor ESJI (KZ)
$=1.500$

$=0.912$

$=1.042$ $\mathrm{sq} \mathrm{m}$ is being built in Russia, with 2 billion sq $\mathrm{m}$
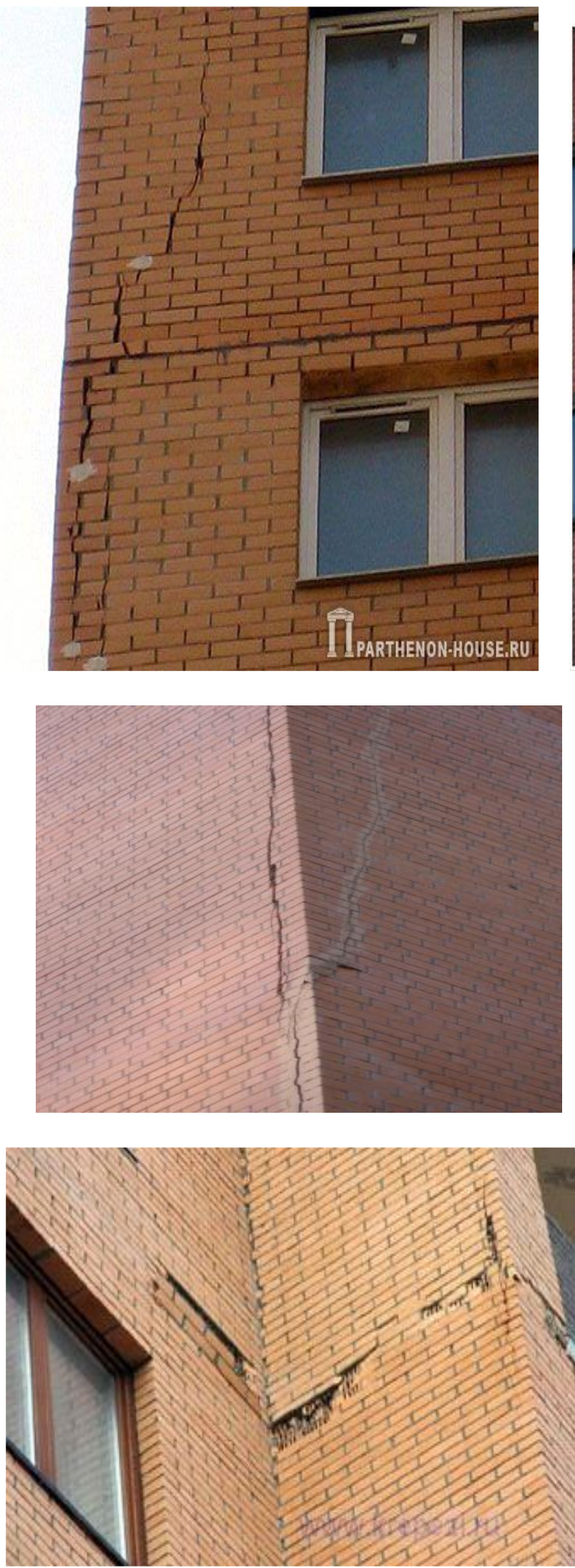

being required in the coming decades.
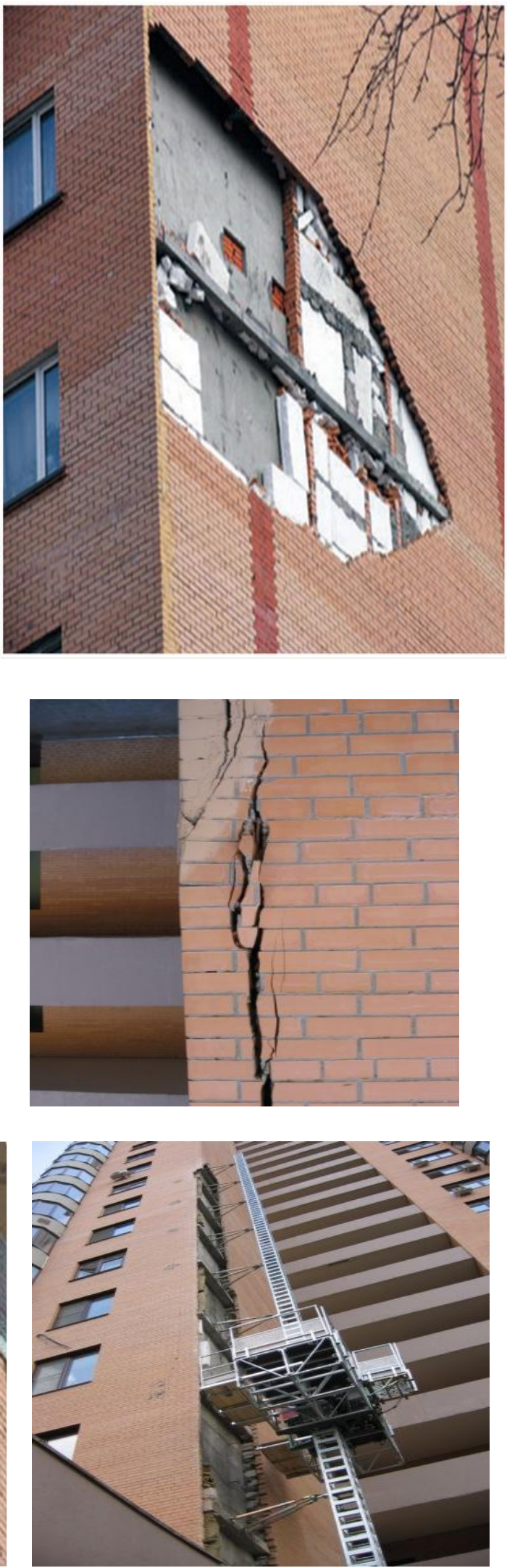

Picture 1 - Demonstration of problems with multi-layer brick facades. [6]

ISPC Industry \& Technology Europe,

Lyon, France 
Tightening of energy consumption regulations for residential areas [5] indispensably leads to use of efficient insulation in constructive layers of outer walls. The use of efficient insulation in outer walls allows to significantly lower heat loss, also thinning the wall thickness in general. Thus, while brick outer walls without efficient insulant in Central Russia shall be as thick as $2000 \mathrm{~mm}$ out of heat saving requirements, $200 \mathrm{~mm}$ is enough when using the efficient insulant.

This fact determined the designers' choice of multilayer constructive solutions with application of efficient insulant for outer walls of buildings that have been massively constructed in the last 2 decades.

The so-called "layered" or hollow brick-work, for example, three-layered, is based on use of heat saving insulant as a middle layer between the outer nonbearing layer (decorative protective, made of brick or other small piece material) and the inner bearing layer of the wall.

However, lately, collapse of walls due to split or fall of parts of brick facing of different size has been happening in the buildings constructed using the three layer outer wall method. (pic.1.) [6].

Even taking into the account the unconditional advantages of multi-layer constructive solutions with efficient insulation over one-layered, the lack of necessary scientific and technological basis leaves open the main problem of their use in construction.

The lack of adequate vapor barrier between the efficient tile insulation and adjacent wall layers typical of such wall structures means that the dew point is situated in the inner face brick layer of the wall, leading to freezing of moisture, accumulated in the "body" of the face brick, which is numerously prone to freezing and defrosting throughout a year.

Taking into account the fact that face brick is a rather long-life material, its collapse in the outer wall is mostly attributed to the proximity and interaction with efficient insulation $[1,3,4]$.

Thus, mechanical and physical, chemical and other features of the efficient tile insulation as well as terms of interaction with adjacent materials, determines the quality of outer walls. It requires experimental research and development of new production technologies, aimed at introduction in mass housing construction of innovative highefficient (energy saving and long-life) materials in outer walls.

It is sad to note that nowadays the lack of low budget constructive solutions for multi-layered walls with application of efficient insulation backed by the necessary legal and regulatory basis and in demand by the market suitable for the Russian climate is a major problem for the construction community. Moreover, the destructive processes going in these structures led to them being forbidden. [2]

In view of the above, since the year 2014, LLC "LAD Systems" has developed in its laboratory the pilot production and is making research of innovative system of composite wall bock - foamthermoblocks for outer and inner walls, including all structural wall layers - effective insulations, brick facade and inner layer (Pic. 2).

Production of composite structural wall foamthermoblocks is based solely on high adhesive quality of rigid polyurethane towards different materials during foam forming, while grouting interstructure space of polyurethane.

The use of rigid polyurethane as an insulation and binding material for getting geometrically perfect wall blocks of the lowest weight, higher thermo technical and strength characteristics as well as high strength-density ratio in special press-forms (matrices) solves many problems, emerging in outer walls.

The innovative quality of the composite structural wall foamthermoblocks for outer walls is its usage of ingenious combination of heat insulating (thermal conduction coefficient, $\lambda=0,025 \mathrm{~W} / \mathrm{m} \cdot{ }^{\circ} \mathrm{C}$ ), vapor insulating (vapor transmission coefficient $\mu$ $=0,018 \mathrm{mg} / \mathrm{m} \cdot \mathrm{hr} \cdot \mathrm{Pa}$ ) and high adhesive qualities of rigid polyurethane towards different materials for getting composite structural wall foam blocks, providing the in-demand façades of face brickwork of minimal thinness. 


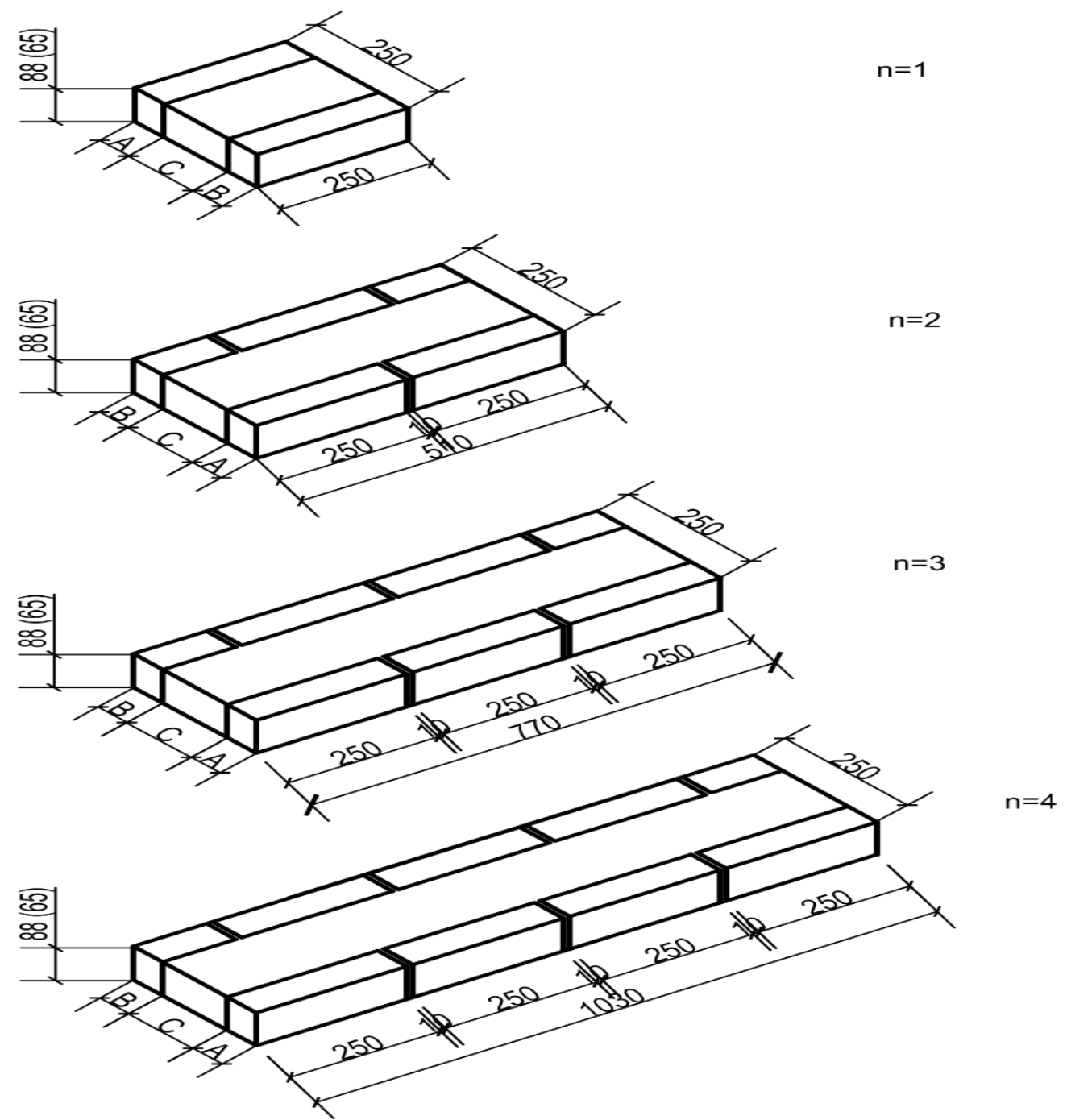

Picture 2 - LLC «LAD Systems» Foamthermoblock (250 mm thick version).

$n$-number of bricks in the block; A - thickness of outer layer made of face brick, B - thickness of inner layer made of ceramic stone, silicate, concrete or other material; $C$-thickness of the layer of poured efficient insulation made of rigid polyurethane; 88(65) - height of standard face brick in Russia, mm; 10 - thickness of vertical masonry joint, mm.

The use of rigid polyurethane as a blocking material allows to build wall blocks of the lowest weight, higher thermo technical and strength characteristics as well as high strength-density ratio. Commercial production for a short period can be organized due to the fact that no wet processes are involved. Composite wall foamthermoblock production technology allows to launch production in any region and even at the construction, if the volumes are sufficient, with application of local construction materials (brick, foam-, gas-, foam polystyrene-, concrete-, silicate blocks, etc).

The most in-demand are composite foamthemroblocks for outer bearing walls of low-rise building, as well self-supporting walls of high-rise frame buildings.

Composite foamthemroblocks for outer walls, which have no counterparts, may be categorized as innovative material in construction area of energy efficient outer walls.

As an option, composite foamthermoblocks may have the structure where the inner heatinsulating layer of rigid polyurethane connects into a whole monolith the face part of the face brick and foamconcrete block of the same height or a part of standard perforated brick sawn across at a distance, determined by thermotechnical calculations.

At that, the length of foamthermoblocks may vary from the length of one brick $(250 \mathrm{~mm})$ to the length of 4 bricks (1000mm) (pic.2).

The thickness of composite foamthermoblocks for self-supporting walls of the coldest Russian region, The Sakha Yakutia Republic, may be no more than $350 \mathrm{~mm}$, and the volume weight of the wall will not exceed $1100 \mathrm{~kg} / \mathrm{cu} \mathrm{m}$, with specific weight of the wall less than $350 \mathrm{~kg} / \mathrm{sq} \mathrm{m}$. The 
preliminary research showed that compressing strength of a wall made of such foamthermoblocks with brick mortar M100 -150 shall make $40-50 \%$ of the strength the brick, forming the block with the strength of foamthermoblocks being no less than $80 \%$ of strength of the brick, forming the block.

Thermotechnical calculations of the outer wall of such blocks show that with the wall thickness of $250 \mathrm{~mm}$ (brick+rigid polyurethane+brick+plaster), thermal resistance Rc equals:

Which, even with minimal thermal uniformity coefficient of the wall $\mathrm{K}$ equaling 0,65 , provides thermal resistance Rc equaling 3,5 W/sq $\mathrm{m} \mathrm{C}$.

At that, low vapor transmission of rigid polyurethane makes it unnecessary to use extra vapor insulating layer.

Composite wall foamthermoblocks with due structural parameters may be used also for inner bearing and self-supporting walls and partitions.

The fundamental difference of composite wall foamthermoblocks for inner walls and partitions from façade foamthermoblocks is lesser thickness of rigid polyurethane $(10-50 \mathrm{~mm})$, due to moderate heat saving requirements to inner walls and partitions.

If thickness of inner bearing wall, as a rule, due to calculation of strength, stableness and deformability of the wall may be no less than 250 $\mathrm{mm}$, then the thickness of partitions is mainly conditioned by requirements to strength, stableness and acoustic isolation and may equal $60 \mathrm{~mm}$ and more.

The use of rigid polyurethane as a blocking material allows to significantly lower the weight of inner walls and partitions as compared to common materials. Thereat, tiles of different thickness (from $15 \mathrm{~mm}$ to $105 \mathrm{~mm}$ ), produced by sawing face and course perforated bricks lengthwise may be used as outer structural layer of the blocks.

As an option, composite wall foamthermoblock for inner walls may consist of 3 layers - structural layer of the face and course perforated bricks sawn lengthwise (ordinary, sesquialter or other format), inner structural layer made of the other part of the sawn brick and middle layer made of rigid polyurethane of $20-50 \mathrm{~mm}$ thickness, connecting them into a whole monolith.

Thereat, to get the fit-out surface of the inner walls of face brick, inner surface of fac bricks may be used as inner layers, making unnecessary the expenses for fit-out of inner walls (for ex., ) inner walls of public places in residential high-rise buildings). The height of such foamthermoblock is regulated by the format of the brick, forming the block.
The researches are planned to be held to design algorithms of thermotechnical and strength calculations of wall structures and, as a whole, to develop scientific and technological basis for introduction of an innovative product with exaplanation of the following main technical parameters:

- universality principle of foamthermoblocks;

- Optimization of geometric formats of composite wall foamthermoblock systems for various climates depending on its strength and heat-saving requirements;

- Pilot design of the building with outer and inner wall out of foamthermoblocks;

- Within cooperation with strategic partners, introduction during construction of pilot residential building with outer and inner walls made of foamthermoblocks and further increase of its volume in construction of low/high-rise buildings.

Whereby, among the key expected competitive advantages of the innovative product under development are:

- availability of legal and regulatory basis and scientific and technological basis for production and introduction of an innovative wall energy-efficient foamthermoblocks, providing the outer and inner wall construction with the necessary operational qualities;

- lasting quality of outer walls;

- optimization (minimization) of outer and inner walls thickness, allowing to enlarge usable floor area;

- optimization (minimization) of outer and inner wall weight, resulting from minimal thickness, leads to less load on the bearing structure;

- low cost (cost effective) due to low material consumption and high technological effectiveness of composite foamthermoblocks production and brickwork process (preliminary, introduction of composite foamthermoblocks will cut cost of facades by $170 \%)$;

- high technological effectiveness of working process and, as a result, good performance while building outer and inner walls is reached by low material consumption of structures and realization of low productive brickwork in workshops, using enlarged formats of composite foamthermoblocks for outer and inner walls.

Thereat, prime cost of certain composite wall foamthermoblocks, consisting of the cost of elements making the block and expenses for its production, and, consequently, cost of the ready wall, may vary greatly depending on the budget requirements. 


\section{References:}

1. Ishchuk MK (2001) Defekty naruzhnykh sten iz mnogosloynoy kladki. //Integral, №1, 2001, pp. $20-22$.

2. Ishchuk MK, Zuev AV (2007) Issledovanie napryazhenno-deformirovannogo sostoyaniya litsevogo sloya iz kirpichnoy kladki pri temperaturno- vlazhnostnykh vozdeystviyakh. // PGS №3, 2007, - pp. 40-43.

3. (2009) Zhurnal "Tekhnologiya stroitel'stva №1.

4. Lyubartovich SA, Morozov YL, Tret'yakov OB (1990) Reaktsionnoe formovanie penopoliuretanov. Moscow: Khimiya, 1990. $288 \mathrm{p}$.

5. Novikov AV (2007) Defekty v oblegchennoy kirpichnoy kladke. // Krovlya. Fasady. Izolyatsiya. №6, 2007.

6. Novikov AV (2007) Prichiny vozniknoveniya defektov v oblegchennoy kladke. /Tekhnologiya stroitel'stva №4(52), 2007.
7. Saunders D, Frish K (1968) Khimiya poliuretanov: Per. s angl. Moscow: Khimiya, 1968.

8. (2009) Federal'nyy zakon ot 23 November 2009. № 261- fz "Ob energosberezhenii i o povyshenii energeticheskoy effektivnosti, i o vnesenii izmeneniy v otdel'nye zakonodatel'nye akty Rossiyskoy Federatsii.

9. Dementyev AG, Dementyev MA, Zinger PA, Metlyakova IR (1999) Effect of the cellular structure on thermal conductivity of rigid closed-cell foam polymers during long-term aging. Journal: Mechanics of Composite Materials, 1999, Volume 35, Number 2, Page 129. DOI: $10.1007 / \mathrm{BF} 02257243$

10. (1995) Dansk Standard DS\EN 253 RU, 1995.01 . 